\title{
An in vitro and in situ evaluation of a diet for cattle added with organic oils
}

\author{
Valenzuela-Rodríguez, Edgar I. ${ }^{1}$; Pámanes-Carrasco, Gerardo A. ${ }^{2}$; Mata-Escobedo, Manuel I. ${ }^{3}$; \\ Medrano-Roldan, Hiram ${ }^{1}$; Reyes-Jáquez, Damián ${ }^{1 *}$ \\ 1 Departamento de Ingeniería Química y Bioquímica, Tecnológico Nacional de México/ I. T. Durango, Dgo., \\ México, C. P. 34080. \\ 2 CONACYT/ UJED, Instituto de Silvicultura e Industria de la Madera, Durango, Dgo., México, G.P. 34160. \\ 3 Tecnológico Nacional de México/Instituto Tecnológico Valle del Guadiana (ITVG), Durango, Dgo., México, \\ C.P. 34000. \\ * Correspondence: damian.reyes@itdurango.edu.mx
}

Citation: Valenzuela-Rodríguez, E I., Pámanes-Carrasco, G. A., MataEscobedo, M. I., Medrano-Roldan, H., \& Reyes-Jáquez, D. (2021). An in vitro and in situ evaluation of a diet for cattle added with organic oils. Agro Productividad. https://doi.org/10.32854/ agrop.v14i12.2115

Editor in Chief: Dr. Jorge Cadena Iñiguez

Received: August 26, 2021. Accepted: November 28, 2021. Published on-line: December 30, 2021.

Agro Productividad, 14(12). December. 2021. pp: 135-143.

This work is licensed under a Creative Commons Attribution-NonCommercial 4.0 International license.

\section{ABSTRACT}

Objective: To perform in vitro and in situ evaluation of a diet for dairy cattle at different rates of fish oil and soybean oil.

Designmethodology/approach: Four treatments with different rates of fish oil (FO) and soybean oil (SO) were evaluated (Control: no added oil; diet 1: 2\% FO; diet 2: 2\% FO and 1.5\% SO; diet 3: 2\% FO and 3\% SO). In vitro digestibility and in situ degradability were evaluated. Ammonia nitrogen, lactic acid, volatile fatty acids (VFAs), and microbial protein were determined. For the in situ evaluation, a protein degradability kinetic was carried out. The means were compared using a Tukey test at a 5\% confidence level.

Results: The proposed diets increased gas production in in vitro kinetics, as the addition of oils increased $(\mathrm{p}<0.001)$ and the kinetic latency time decreased $(\mathrm{p}<0.001)$. All diets decreased the production of short-chain fatty acids $(\mathrm{p}<0.001)$. The production of ammonia nitrogen and lactic acid did not differ compared to the control $(\mathrm{p}<0.05)$. Diet 3 had a higher production of propionic acid in comparison to diet 1 and 2 . In the in situ kinetic, the " $k d$ " rate increased as more oils were added.

Study limitations/implications: Although all treatments increased the production (milliliters) of $\mathrm{CH}_{4}$ and $\mathrm{CO}_{2}$, the gas production had a proportional increase, as a result of a better use of the diets.

Findings/conclusions: The addition of oils produced changes in the fermentation patterns and in the degradation of the protein at the ruminal level, increasing bypass protein. This offers an opportunity to improve performance in certain production situations.

Keywords: in vitro digestibility, in situ degradability, gas production.

\section{INTRODUGTION}

Conjugated linoleic acid (CLA) - a fatty acid found naturally in the dairy and meat products of ruminants - has been identified as a potential anti-obesogenic, anticancerogenic, and enhancer of the immune and inflammatory response (Den Hartigh, 2018; Whigham, Watras, and Schoeller, 2018). CLA is an 18-carbon PUFA formed as an intermediate, during the biohydrogenation $(\mathrm{BH})$ of linoleic acid (C18:2 cis-9, cis-12, LA) and alpha-linolenic acid (C18:3 cis-9, cis-12, cis-15, ALA), and their transformation into

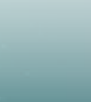


stearic acid (G18:0, SA), or by the endogenous conversion of trans-vaccenic acid (C18:1 $\mathrm{t}-11$, TVA) by the action of the $\Delta 9$-desaturase enzyme in the mammary gland (Khanal and Olson, 2004). LA and ALA are found in high proportions in the lipids of fodder and in some supplements, such as oils. Castillo et al. (2013) point out that supplementing diets with LA- and ALA-rich soybean oil reduces short-chain fatty acids and increases long-chain unsaturated fatty acids (UFA) - especially TVA and CLA. For its part, fish oil contains eicosapentaenoic acid (C20:5 n-3, EPA) and docosahexaenoic acid (C22:6 n-3, DHA); adding these acids to ruminant diets increases CLA concentration in milk and meat (Wassowska et al., 2006). This has an impact on the BH process of the UFA, increasing the contribution of TVA - which serves as a substrate for the endogenous formation of CLA (Shingfield et al., 2006).

Furthermore, ruminants make a significant contribution to the total greenhouse gas (GHG) emissions of the agricultural sector (Sejian and K. Naqvi, 2012). One way to decrease methanogenesis in ruminants is to include PUFAs in the diet, since UFAs serve as electron acceptors during the biohydrogenation process, causing a depression in methane production (Broucek, 2018). Methane represents a significant loss of dietary energy: a 2-12\% loss of gross energy intake (Johnson and Johnson, 1995). Reducing enteric methane production could also increase feed efficiency.

Taking into account that both the production of GHG and the fatty acids accumulated in the milk and meat of the ruminant take place at the metabolic level, determining the effects of the addition of organic oils in its diet is an important step. Therefore, the objective of the present study was to evaluate the effects of adding FO and $\mathrm{SO}$ on the parameters of ruminal fermentation and the in vitro and in situ degradability kinetics. This evaluation allowed us to find out the metabolic differences between the different oil levels.

\section{MATERIALS AND METHODS}

The evaluated diets contained a balanced feed mixture (6\% soybean husk, $16 \%$ distillers' dried grains, $6 \%$ sugarcane molasses, $20 \%$ rolled corn, $17.5 \%$ ground corn, $3.5 \%$ mineral mixture, $4 \%$ cottonseed, $5.8 \%$ soybean paste, $11.2 \%$ ground sorghum, $4 \%$ cottonseed meal, and $6 \%$ wheat bran), silage, and alfalfa (30, 29, and 41\%, respectively) added with different ratios of SO and FO (Control: without added oil; diet 1: 2\% FO; diet 2: 2\% FO and $1.5 \% \mathrm{SO}$; diet 3: $2 \% \mathrm{FO}$ and $3 \% \mathrm{SO}$ ). For the gas production technique proposed by Menke et al. (1979), the components of the diets were dried in an oven at $55^{\circ} \mathrm{C}$ for 48 $\mathrm{h}$, ground, and sieved ( $1 \mathrm{~mm}$ mesh) separately. One gram of dry matter (DM) from each diet (with their respective oils) was added to $250-\mathrm{mL}$ fermentation flasks with $120 \mathrm{~mL}$ of a 2:1 mixture of ruminal fluid and artificial saliva (Macromineral solution: $1 \mathrm{~L}$ distilled $\mathrm{H}_{2} \mathrm{O}, 5.7 \mathrm{~g} \mathrm{Na}_{2} \mathrm{HPO}_{4}, 6.2 \mathrm{~g} \mathrm{K \textrm {KH } _ { 2 }} \mathrm{HPO}_{4}, 0.6 \mathrm{~g} \mathrm{MgSO} 47 \mathrm{H}_{2} \mathrm{O}$; micromineral solution: 100 $\mathrm{mL}$ distilled $\mathrm{H}_{2} \mathrm{O}, 13.2 \mathrm{~g} \mathrm{CaCL}{ }_{2} \bullet \mathrm{H}_{2} \mathrm{O}, 10 \mathrm{~g} \mathrm{MnCl}_{2} \bullet 4 \mathrm{H}_{2} \mathrm{O}, 1 \mathrm{~g} \mathrm{CoCl}{ }_{2} \bullet 6 \mathrm{H}_{2} \mathrm{O}$, and $8 \mathrm{~g}$ $\mathrm{FeCl}_{3} \bullet 6 \mathrm{H}_{2} \mathrm{O}$; buffer solution: $1 \mathrm{~L}$ distilled $\mathrm{H}_{2} \mathrm{O}$ and $39 \mathrm{~g} \mathrm{NaHCO}$; reducing solution: $100 \mathrm{~mL}$ distilled $\mathrm{H}_{2} \mathrm{O}, 4 \mathrm{~mL} 1 \mathrm{~N} \mathrm{NaOH}$ and $625 \mathrm{mg} \mathrm{Na} 2 \mathrm{~S} \bullet 9 \mathrm{H}_{2} \mathrm{O}$; and resazurin solution: $100 \mathrm{~mL}$ distilled $\mathrm{H}_{2} \mathrm{O}$ and $100 \mathrm{mg}$ resazurin); $\mathrm{CO}_{2}$ was used to establish an anaerobic environment; the fermentation flasks were incubated in an ANKOM Daisy ${ }^{\text {II }}$ equipment for $96 \mathrm{~h}$. The accumulated gas pressures were measured using an automated measuring 
equipment (ANKOM RF Gas production System) equipped with a pressure transducer connected to each fermentation flask. Measurements were taken at $0,0.5,1,2,3,6,12$, $24,36,48,72$, and $96 \mathrm{~h}$ after inoculation. The gas production profiles were adjusted to the Gompertz equation (Tjørve and Tjørve, 2017) (Equation 1).

$$
G P=G \max e^{-A e^{-k t}}
$$

Where $G P=$ gas production, $G \max =$ maximum gas production, $A=$ adaptation phase, and $k=$ gas production rate.

Gas samples were taken from the upper section of the fermentation flasks at $24 \mathrm{~h}$, to measure the production of $\mathrm{CO}_{2}$ and $\mathrm{CH}_{4}$, using a Biogas 5000 equipment. At the end of the fermentations $(96 \mathrm{~h}$ ), the residues of fermentation were centrifuged at 2,500 rpm for $5 \mathrm{~min}$, then they were filtered, and used to analyze VFAs, ammonia nitrogen, and lactic acid. The VFAs were analyzed in a 6890N gas chromatograph (Agilent Technologies, Wilmington, DE) equipped with a flame ionization detector and an HP-Innowax polyethylene glycol capillary column (30 $\mathrm{m} \times 0.32 \mathrm{~mm} \times 0.15 \mu \mathrm{m}, \mathrm{J} \& \mathrm{~W}$ Scientifics). The oven was set up at $80^{\circ} \mathrm{C}$; after 1 min, the temperature was raised to $120^{\circ} \mathrm{C}$, with a $20{ }^{\circ} \mathrm{C} / \mathrm{min}$ increase, until it reached $205^{\circ} \mathrm{C}$; afterwards, the temperature was increased $10^{\circ} \mathrm{C} / \mathrm{min}$ (for 2 minutes). Nitrogen was used as carrier gas at a constant flow rate of $40 \mathrm{ml} / \mathrm{min}$, injecting $1 \mu \mathrm{L}$ of sample.

The ruminal environment was evaluated through the analysis of ammonia nitrogen, lactic acid, in vitro digestibility of dry matter (IVDDM), and microbial protein. The ammonia nitrogen in the samples (Galyean, 2010) was subject to a spectrometry analysis at a wavelength of $630 \mathrm{~nm}$ in a Genesys 10S VIS Thermo Scientific spectrometer; the lactic acid in the samples (Borshchevskaya et al., 2016) was analyzed using the same equipment at $390 \mathrm{~nm}$ with $0.2 \% \mathrm{FeCl}_{3}$. The $I V D D M$ was evaluated using nylon bags $\mathrm{F} 57$ $(\mathrm{ANKOM}) \mathrm{s}$ with $0.5 \mathrm{~g}$ of each diet in $1.6 \mathrm{~L}$ of a mixture of solution A:solution $\mathrm{B}(5: 1)$ (Solution A: $10 \mathrm{~g} / \mathrm{L} \mathrm{KH}_{2} \mathrm{PO}_{4}, 0.5 \mathrm{~g} / \mathrm{L} \mathrm{MgSO}_{4}, 0.5 \mathrm{~g} / \mathrm{L} \mathrm{NaCl}, 0.1 \mathrm{~g} / \mathrm{L} \mathrm{CaCl}_{2} \bullet 2 \mathrm{H}_{2} \mathrm{O}$, and $0.5 \mathrm{~g} / \mathrm{L}$ urea; Solution B: $15 \mathrm{~g} / \mathrm{L} \mathrm{Na}_{2} \mathrm{CO}_{3}$ and $\left.1 \mathrm{~g} / \mathrm{L} \mathrm{Na}_{2} \mathrm{~S} \bullet 9 \mathrm{H}_{2} \mathrm{O}\right)$ and $400 \mathrm{~mL}$ of ruminal fluid; 5-L glass incubation jars were used in an ANKOM Daisy II incubator at $39^{\circ} \mathrm{C}$ for $48 \mathrm{~h} ; \mathrm{CO}_{2}$ was used to establish an anaerobic environment. At the end of the incubation period, the nylon bags F57 (ANKOM) were dried in an oven at $55^{\circ} \mathrm{C}$ for $48 \mathrm{~h}$ and the IVDDM was determined by weight difference. The IVDDM value of each diet and its gas production at $48 \mathrm{~h}$ were used to calculate the microbial protein using Equation 2, according to Blümmel, Steinga $\beta$, and Becker (1997).

$$
M P\left(\frac{m g}{g \operatorname{de} M S}\right)=I V D D M-\left(G P_{48} * 2.2\right)
$$

Where: $M P=$ microbial protein, $I V D D M=$ in vitro digestibility of dry matter, and $G P_{48}=$ gas production at 48 hours. 
The in situ evaluation was carried out in three "Angus" cattle with ruminal fistula, using the nylon bag technique (Mehrez \& Ørskov, 1977): $20 \times 10 \mathrm{~cm}$ bags with an average pore of 50 microns were used. The bags were previously dried at $60^{\circ} \mathrm{C}$ for $24 \mathrm{~h} ; 10 \mathrm{~g}$ of DM of each diet (with their respective oils) were placed in each one; and two repetitions of each time were made $(0,3,6,12,18,24,36,48,72$, and $96 \mathrm{~h})$. The bags were placed in the ventral part of the rumen and were introduced in the reverse order of their incubation time; all of them were removed together. The zero-hour bags were introduced and immediately removed, once they were moistened with ruminal fluid (Nocek \& Russell, 1988). The bags were thoroughly washed with running water and then dried in an oven at $55{ }^{\circ} \mathrm{C}$ for 48 h. Crude protein $(\mathrm{CP})$ was determined from the residues of each bag with the Kjeldahl method, using the $\mathrm{N} \times 6.25$ factor (AOAC 991.20). In situ degradation parameters were estimated with the modifications made by McDonalds (1981) to the model proposed by Orskov and Mcdonald (1979) (Equation 3).

$$
d=a+b\left(1-e^{-k d^{*} t}\right)
$$

Where: $d=$ degradability at $t$ time, $t=$ incubation time, $a=$ soluble or rapidly degradable fraction, $b=$ insoluble but potentially degradable fraction (\%), and $k d=$ degradation constant of " $b$ ".

The non-digestible fraction (" $C$ ") and potentially digestible fraction (" $P D$ ") were calculated using Equation 4, and the effective degradability ("ED") was calculated using Equation 5.

$$
C=100-(a+b)
$$

Where: $C=$ non-digestible fraction $(\%), P D=$ potentially digestible fraction $(a+b)$.

$$
E D=a+[(b * k d) /(k d+k p)]
$$

Where: $E D=$ effective degradability, $k p=5 \% / \mathrm{h}$ constant ruminal passage rate, and $k d=$ degradation constant of " $b$ ".

A completely randomized experimental design was used; a mean comparison Tukey test was performed. We considered that there was a significant difference when $p<0.05$. A statistical analysis was performed with the SigmaPlot [12.0] statistical software.

\section{RESULTS AND DISCUSSION}

In the parameters obtained for the Gompertz equation (Table 1), the maximum gas production ("Gmax") increased $(\mathrm{p}<0.001)$ as more oil was added and the "A" lag phase decreased $(\mathrm{p}<0.001)$. In diet 3 , the " $k$ " gas production rate increased $(\mathrm{p}<0.05)$ compared to control. The increase in "Gmax" indicates a greater fermentation of organic matter (Blümmel and Ørskov, 1993). This increase differs from the results of Toral et al. (2009) 
in sheep, who used a mixture of FO with sunflower oil (1 and 2\%), observing a slight decrease in the accumulated gas production, without changing the gas production rate. These differences may be the result of the type and quantity of oils, as well as of the different concentrate rates used in each study (Wachira et al., 2000; Ueda et al., 2003; Shingfield et al., 2008). Beuvink and Spoelstra (1992) point out that the total amount of gas produced depends on the composition of the final fermentation products. Starch fermentation produces more gas than glucose or cellulose fermentation. Therefore, the increase in "Gmax" obtained in the present study can be attributed to an increase in the population of amylolytic bacteria, as a consequence of the toxic effect that oils have on cellulolytic bacteria and protozoa (Harfoot and Zealand, 1997; Yang et al., 2009; Palmquist and Jenkins, 2017; Roy et al., 2017; Lima et al., 2019). The decrease in the number of cellulolytic bacteria could also explain the decrease in total volatile fatty acids (VFA) (Table 4), since cellulose fermentation produces the highest quantity of VFAs (Beuvink and Spoelstra, 1992).

Within the parameters of ruminal fermentation (Table 2), the IVDDM decreased in diet $2(63.9 \%)$ compared to control and diet 1 (68.2 and 67\%, respectively; $p<0.05)$. The ammonia nitrogen and lactic acid concentration is not affected by the addition of oils compared to the control diet. Microbial protein synthesis decreased as more oils were added $(\mathrm{p}<0.001)$. The decrease in IVDDM observed in diet 2 differs from the results obtained by Roy et al. (2017), who did not observe differences in IVDDM when they used different oils (0, 3, and 4\%). In contrast, El-Sherbiny et al. (2016) observed a decrease in IVDDM with FO and SO mixtures at 5 and $7 \%$ of total addition.

Table 3 shows an increase $(\mathrm{p}<0.001)$ in the production of $\mathrm{CO}_{2}$ and $\mathrm{CH}_{4}$, related to higher gas production $(\operatorname{Gmax})$. On one hand, the ratio is not significantly affected, indicating that diets do not change the rate in which it is produced. No significant differences were

Table 1. Effect of the addition of organic oils on the parameters of the Gompertz equation.

\begin{tabular}{l|c|c|c|c|c|c} 
& Control & DIET 1 & DIET 2 & DIET 3 & EE $^{*}$ & p-value $^{\mathrm{a}}$ \\
\hline $\operatorname{Gmax}(\mathrm{mL})$ & $62.1 \pm 3.38^{\mathrm{c}}$ & $96.6 \pm 4.01^{\mathrm{b}}$ & $138.7 \pm 12.09^{\mathrm{a}}$ & $140.4 \pm 10.46^{\mathrm{a}}$ & 18.75 & $<0.001$ \\
\hline$A(\mathrm{~h})$ & $15.5 \pm 2.21^{\mathrm{a}}$ & $7.2 \pm 1.09^{\mathrm{b}}$ & $4.5 \pm 0.59^{\mathrm{bc}}$ & $3.7 \pm 0.21^{\mathrm{bc}}$ & 2.69 & $<0.001$ \\
\hline$k\left(\mathrm{~h}^{-1}\right)$ & $0.06 \pm 0.004^{\mathrm{b}}$ & $0.14 \pm 0.029^{\mathrm{ab}}$ & $0.24 \pm 0.117^{\mathrm{ab}}$ & $0.29 \pm 0.075^{\mathrm{a}}$ & 0.05 & $<0.05$ \\
\hline a, b, c, d : the same letters indicate that there is no statistically significant difference, $\mathrm{EE}^{*} \cdot$ Standard error
\end{tabular}

a, b, c, d: the same letters indicate that there is no statistically significant difference, $\mathrm{EE}^{*}$ : Standard error.

Table 2. Effect of the addition of organic oils on the parameters of ruminal fermentation.

\begin{tabular}{|c|c|c|c|c|c|c|}
\hline & Control & DIET 1 & DIET 2 & DIET 3 & $\mathbf{E E}^{*}$ & p-value \\
\hline DIVMS: (\%) & $68.2 \pm 1.20^{\mathrm{a}}$ & $67.0 \pm 2.21^{\mathrm{a}}$ & $63.9 \pm 2.42^{b}$ & $65.9 \pm 1.10^{\mathrm{ab}}$ & 0.91 & $<0.05$ \\
\hline Ammonia nitrogen $(\mathrm{mg} / \mathrm{dL})$ & $13.0 \pm 1.48^{\mathrm{ab}}$ & $10.8 \pm 1.72^{b}$ & $13.8 \pm 0.39^{\mathrm{a}}$ & $12.8 \pm 0.04^{\mathrm{ab}}$ & 0.63 & $<0.05$ \\
\hline $\begin{array}{l}\text { Calculated microbian } \\
\text { protein }(\mathrm{mg} / \mathrm{g} \mathrm{DM})\end{array}$ & $564.6 \pm 16.11^{\mathrm{a}}$ & $462.9 \pm 17.1^{\mathrm{b}}$ & $364.6 \pm 37.39^{c}$ & $381.0 \pm 14.57^{\mathrm{c}}$ & 45.80 & $<0.001$ \\
\hline
\end{tabular}

a, b, c, d: the same letters indicate that there is no statistically significant difference, EE* : Standard error. In vitro digestibility of dry matter (IVDDM). 
Table 3. Effect of the addition of organic oils on the production of methane and carbon dioxide.

\begin{tabular}{l|c|c|c|c|c|c} 
& Control & DIET 1 & DIET 2 & DIET 3 & EE & p-value $^{*}$ \\
\hline $\mathrm{CO}_{2}(\mathrm{ml})$ & $33.1 \pm 1.14^{\mathrm{c}}$ & $64.4 \pm 0.02^{\mathrm{b}}$ & $58.7 \pm 5.05^{\mathrm{b}}$ & $83.0 \pm 7.94^{\mathrm{a}}$ & 10.30 & $<0.001$ \\
\hline $\mathrm{CH}_{4}(\mathrm{ml})$ & $5.1 \pm 0.08^{\mathrm{c}}$ & $10.3 \pm 0.14^{\mathrm{b}}$ & $9.5 \pm 0.31^{\mathrm{b}}$ & $12.7 \pm 0.52^{\mathrm{a}}$ & 1.58 & $<0.001$ \\
\hline $\mathrm{CO}_{2}(\%)$ & $71.7 \pm 0.25$ & $76.9 \pm 0.3$ & $75.6 \pm 3.7$ & $73.1 \pm 3.32$ & 1.17 & $\mathrm{nssd}$ \\
\hline $\mathrm{CH}_{4}(\%)$ & $11.2 \pm 0.60^{\mathrm{b}}$ & $12.3 \pm 0.15^{\mathrm{a}}$ & $12.2 \pm 0.05^{\mathrm{a}}$ & $11.2 \pm 0.25^{\mathrm{b}}$ & 0.30 & $<0.05$ \\
\hline $\mathrm{CH}_{4} / \mathrm{CO}_{2}$ & $0.15 \pm 0.007$ & $0.16 \pm 0.002$ & $0.16 \pm 0.008$ & $0.15 \pm 0.008$ & 0.002 & $\mathrm{nssd}$ \\
\hline
\end{tabular}

a, b, c, d: the same letters indicate that there is no statistically significant difference, nssd: no statistically significant difference, EE* : Standard error.

found in the percentage of that was produced. On the other hand, the increase of the propionic acid production (Table 4) in diet 3 and the control compared to diets 1 and 2 (23.8 and 23.1\%: 16.7 and 18.3\%, respectively; $\mathrm{p}<0.05)$, decreases the percentage of $(11.2$ and $11.2 \%$ : 12.3 and $12.2 \%$, respectively; $\mathrm{p}<0.05)$, as well as the $\mathrm{A} / \mathrm{P}$ ratio $(1.8$ and 1.9 : 2.8 and 2.7 , respectively; $\mathrm{p}<0.05)$. The production of TVFAs decreased with the addition of oils $(\mathrm{p}<0.001)$; consequently, there was a greater decrease in diet $3(10.1 \mathrm{mM})$ than in control $(17.5 \mathrm{mM})$. These results match the findings of several authors (Broudiscou and Lassalas, 1991; Zhang et al., 2008; Martin et al., 2009; Vargas et al., 2020); as propionic fermentation increases, the hydrogen uptake increases and methane production decreases (Boadi et al., 2004).

In the case of in situ protein degradability (Table 5), diet 3 presents highly significant effects $(\mathrm{p}<0.001)$ in the " $C$ " non-digestible fraction -i.e., a greater increase with respect to control (48.9 and $41.0 \%$, respectively). Likewise, its potentially digestible fraction $(P D)$ shows a greater decrease (51.0 and 58.9\%). A similar effect is observed in diet 1 and 2. The $E D$ in diets 2 and 3 is greater than in control (31.6 and 30.6: 25.5\%, respectively; $\mathrm{p}<0.05)$; a similar effect is observed with " $k d$ " (0.045 and 0.061: $0.025 \mathrm{~h}^{-1}$, respectively; $\left.\mathrm{p}<0.001\right)$. The " $a$ " fraction of the diets did not present a significant difference ( $\mathrm{p}>0.05)$ compared to control. The decrease in the $P D$ fraction and increase in $C$ is consistent with a study carried out by Ferreira et al. (2016) in lambs, in which the digestibility of CP in the total digestive tract decreased when a mixture of FO and $\mathrm{SO}$ was supplemented: the higher the SO concentration, the lower the apparent digestibility. This decrease in protein degradability is related to the decrease in microbial protein synthesis (Table 2), which could be the result of an inhibition in microbial growth caused by the PUFAs present in FO and SO (Maia et

Table 4. Effect of the addition of organic oils on the production of volatile fatty acids (VFAs).

\begin{tabular}{l|c|c|c|c|c|c}
\hline & Control & DIET 1 & DIET 2 & DIET 3 & EE $^{*}$ & p-value $^{-}$ \\
\hline Acetic acid (\%) & $44.2 \pm 6.92$ & $46.5 \pm 2.63$ & $48.6 \pm 2.73$ & $44.7 \pm 1.78$ & 0.99 & nssd \\
\hline Propionic acid (\%) & $23.1 \pm 0.94^{\mathrm{a}}$ & $16.7 \pm 1.41^{\mathrm{b}}$ & $17.6 \pm 1.15^{\mathrm{b}}$ & $23.8 \pm 1.78^{\mathrm{a}}$ & 1.83 & $<0.05$ \\
\hline Butiric acid (\%) & $27.8 \pm 5.97$ & $31.9 \pm 1.22$ & $28.8 \pm 2.65$ & $26.6 \pm 3.56$ & 1.13 & $\mathrm{nssd}$ \\
\hline TVFA $(\mathrm{mM})$ & $17.5 \pm 1.11^{\mathrm{a}}$ & $11.8 \pm 1.12^{\mathrm{bc}}$ & $13.1 \pm 0.99^{\mathrm{b}}$ & $10.1 \pm 0.40^{\mathrm{c}}$ & 1.58 & $<0.001$ \\
\hline A/P ratio & $1.9 \pm 0.37^{\mathrm{b}}$ & $2.8 \pm 0.39^{\mathrm{a}}$ & $2.7 \pm 0.16^{\mathrm{a}}$ & $1.8 \pm 0.06^{\mathrm{b}}$ & 0.26 & $<0.05$ \\
\hline
\end{tabular}

a, b, c, d: the same letters indicate that there is no statistically significant difference, nssd: no statistically significant difference, EE* : Standard error. TVFA: total volatile fatty acids. 
Table 5. Effect of the addition of organic oils on the in situ ruminal degradation parameters and effective protein degradability of each diet.

\begin{tabular}{|c|c|c|c|c|c|c|}
\hline & Control & DIET 1 & DIET 2 & DIET 3 & EE* & p-value \\
\hline$a(\%)$ & $8.3 \pm 2.49^{\mathrm{ab}}$ & $13.4 \pm 0.33^{\mathrm{a}}$ & $7.6 \pm 1.75^{\mathrm{ab}}$ & $5.7 \pm 2.78^{b}$ & 1.64 & $<0.05$ \\
\hline$b(\%)$ & $50.5 \pm 4.22$ & $43.2 \pm 0.15$ & $50.1 \pm 1.54$ & $45.3 \pm 3.64$ & 6.73 & nssd \\
\hline Non-digestible fraction " $C$ " (\%) & $41.0 \pm 1.72^{\mathrm{c}}$ & $43.2 \pm 0.48^{\mathrm{b}}$ & $42.1 \pm 0.21^{\mathrm{bc}}$ & $48.9 \pm 0.86^{\mathrm{a}}$ & 1.75 & $<0.001$ \\
\hline $\begin{array}{l}\text { Potentially digestible fraction } \\
" D P "(\%)\end{array}$ & $58.9 \pm 1.72^{\mathrm{a}}$ & $56.7 \pm 0.48^{b}$ & $57.8 \pm 0.21^{\mathrm{ab}}$ & $51.0 \pm 0.86^{\mathrm{c}}$ & 1.75 & $<0.001$ \\
\hline $\begin{array}{l}\text { Effective degradability " } D E "(\%) ; \\
\text { para } k p=5 \% / \text { h }\end{array}$ & $25.5 \pm 1.12^{\mathrm{b}}$ & $28.8 \pm 1.62^{\mathrm{ab}}$ & $31.6 \pm 1.17^{\mathrm{a}}$ & $30.6 \pm 1.36^{\mathrm{a}}$ & 1.34 & $<0.05$ \\
\hline
\end{tabular}

a, b, c, d: the same letters indicate that there is no statistically significant difference, nssd: no statistically significant difference, EE*: Standard error, $C=$ non-digestible fraction $(C=100-(a+b)), P D=$ potentially digestible fraction $(P D=a+b), E D$ : effective degradability for $k p=5 \% /$ hour $\left(E D=a+\left[\left(b^{*} k d\right) /(k d+k p)\right]\right)$.

al., 2010; Ferreira et al., 2016). These findings match the tests carried out by El-Sherbiny $e t$ al. (2016), who recorded a reduction in the total count of bacteria as a mixture of SO and FO increased to 3, 5, and $7 \%$ of total addition.

\section{CONGLUSIONS}

The addition of oils produced changes in the fermentation patterns that suggest a modification in the microbial populations. Protein degradation is also modified, increasing bypass protein. This offers an opportunity to improve performance in certain production situations.

\section{REFERENGES}

Beuvink, J. M. W., \& Spoelstra, S. F. (1992). Interactions between substrate, fermentation end-products, buffering systems and gas production upon fermentation of different carbohydrates by mixed rumen microorganisms in vitro. 37, 505-509.

Blümmel, M., \& Orskov, E. R. (1993). Comparison of in vitro gas production and nylon bag degradability of roughages in predicting feed intake in cattle. Animal Feed Science and Technology, 40(2-3), 109-119. https://doi.org/10.1016/0377-8401(93)90150-I

Blümmel, M., Steinga, H., \& Becker, K. (1997). The relationship between in vitro gas production, in vitro microbial biomass yield and $15 \mathrm{~N}$ incorporation and its implications for the prediction of voluntary feed intake of roughages. British Journal of Nutrition, 77(6), 91 1-921. https://doi.org/10.1079/bjn 19970089

Boadi, D., Benchaar, C., Chiquette, J., \& Massé, D. (2004). Mitigation strategies to reduce enteric methane emissions from dairy cows: Update review. Canadian Journal of Animal Science, 84(3), 319-335. https:// doi.org/10.4141/A03-109

Borshchevskaya, L. N., Gordeeva, T. L., Kalinina, A. N., \& Sineokii, S. P. (2016). Spectrophotometric determination of lactic acid. Journal of Analytical Chemistry, 71(8), 755-758. https://doi.org/10.1134/ S1061934816080037

Broucek, J. (2018). Options to methane production abatement in ruminants: A review. Journal of Animal and Plant Sciences, 28(2), 348-364.

Broudiscou, L., \& Lassalas, B. (1991). Linseed oil supplementation of the diet of sheep: effect on the in vitro fermentation of amino acids and proteins by rumen microorganisms. Animal Feed Science and Technology, 33(1-2), 161-171. https://doi.org/10.1016/0377-8401(91)90054-V

Castillo V, J., Olivera A, M., \& Carulla F, J. (2013). Descripción Del Mecanismo Bioquímico De La Biohidrogenación En El Rumen De Ácidos Grasos Poliinsaturados: Una Revisión. Revista U.D.C.A Actualidad E Divulgación Científica, 16(2), 459-468. 
Den Hartigh, L. J. (2018). Conjugated linoleic acid effects on cancer, obesity, and atherosclerosis: A review of pre-clinical and human trials with current perspectives. Nutrients, 11(2), 1-29. https://doi.org/10.3390/ nu 11020370

El-Sherbiny, M., Cieslak, A., Pers-Kamczyc, E., Szczechowiak, J., Kowalczyk, D., \& Szumacher-Strabel, M. (2016). Short communication : A nanoemulsified form of oil blends positively affects the fatty acid proportion in ruminal batch cultures. Journal of Dairy Science, 99(1), 399-407. https://doi.org/10.3168/ jds.2015-9328

Ferreira, E. M., Pires, A. V., Susin, I., Biehl, M. V., Gentil, R. S., Parente, M. de O. M., ... de Almeida, E. (2016). Nutrient digestibility and ruminal fatty acid metabolism in lambs supplemented with soybean oil partially replaced by fish oil blend. Animal Feed Science and Technology, 216, 30-39. https://doi. org/10.1016/j.anifeedsci.2015.09.007

Galyean, M. May, T. (2010). Laboratory procedure in animal nutrition research. Department of Animal and Life Science. New .., 193. Retrieved from ftp://196.44.109.146/data/Buckup05062013/Gaston/Alfred documents/graggio/Alfred/Research/Literature_papers/metodology/Laboratory procedures in animal nutrition research. Galyean 1997.pdf

Harfoot, C. O., \& Zealand, N. (1997). Lipid metabolism in the rumen. In The Rumen Microbial Ecosystem (pp. $382-426)$.

Johnson, K. A., \& Johnson, D. E. (1995). Methane emissions from cattle. Journal of Animal Science, 73(8), 2483 2492. https://doi.org/10.2527/1995.7382483x

Khanal, R. C., \& Olson, K. C. (2004). Factors Affecting Conjugated Linoleic Acid(CLA) Content in Milk, Meat, and Egg: A Review. Pakistan Journal of Nutrition, 3(2), 82-98. https://doi.org/10.3923/pjn.2004.82.98

Lima, P. R., Apdini, T., Freire, A. S., Santana, A. S., Moura, L. M. L., \& Nascimento, J. C. S. (2019). Dietary supplementation with tannin and soybean oil on intake, digestibility, feeding behavior, ruminal protozoa and methane emission in sheep. Animal Feed Science and Technology, 249(January), 10-17. https://doi.org/10.1016/j.anifeedsci.2019.01.017

Maia, M. R., Chaudhary, L. C., Bestwick, G. S., Richardson, A. J., McKain, N., Larson, T. R., ... Wallace, R. J. (2010). Toxicity of unsaturated fatty acids to the biohydrogenating ruminal bacterium, Butyrivibrio fibrisolvens. BMC Microbiology, 10, 8-10. https://doi.org/10.1186/1471-2180-10-52

Martin, G., Ferlay, A., Chilliard, Y., \& Doreau, M. (2009). Decrease in methane emissions in dairy cows with increase in dietary linseed content. Proceedings of the British Society of Animal Science, 2009(124), 21-21. https://doi.org/10.1017/s175275620002860x

McDonald, I. (1981). SHORT NOTE: A revised model for the estimation of protein degradability in the rumen. The Journal of Agricultural Science, 96(1), 251-252. https://doi.org/10.1017/S0021859600032081

Mehrez, A. Z., \& Ørskov, E. R. (1977). A study of the artificial fibre bag technique for determining the digestibility of feeds in the rumen. The Journal of Agricultural Science, 88(3), 645-650. https://doi. org/10.1017/S0021859600037321

Menke, K. H., Raab, L., Salewski, A., Steingass, H., Fritz, D., \& Schneider, W. (1979). The estimation of the digestibility and metabolizable energy content of ruminant feedingstuffs from the gas production when they are incubated with rumen liquor in vitro. The Journal of Agricultural Science, 93(1), 217-222. https:// doi.org/10.1017/S0021859600086305

Nocek, J. E., \& Russell, J. B. (1988). Protein and Energy as an Integrated System. Relationship of Ruminal Protein and Carbohydrate Availability to Microbial Synthesis and Milk Production. Journal of Dairy Science, 71(8), 2070-2107. https://doi.org/10.3168/jds.S0022-0302(88)79782-9

Orskov, E. R., \& Mcdonald, I. (1979). The estimation of protein degradability in the rumen from incubation measurements weighted according to rate of passage. The Journal of Agricultural Science, 92(2), 499-503. https://doi.org/10.1017/S0021859600063048

Palmquist, D. L., \& Jenkins, T. G. (2017). A 100-Year Review: Fat feeding of dairy cows. Journal of Dairy Science, 100(12), 10061-10077. https://doi.org/10.3168/jds.2017-12924

Roy, A., Mandal, G. P., \& Patra, A. K. (2017). Effects of different vegetable oils on rumen fermentation and conjugated linoleic acid concentration in vitro. Veterinary World, 10(1), 11-16. https://doi.org/10.14202/ vetworld.2017.11-16

Sejian, V., \& K. Naqvi, S. M. (2012). Livestock and Climate Change: Mitigation Strategies to Reduce Methane Production. Greenhouse Gases - Capturing, Utilization and Reduction. https://doi.org/10.5772/32014

Shingfield, K. J., Ahvenjärvi, S., Toivonen, V., Vanhatalo, A., Huhtanen, P., \& Griinari, J. M. (2008). Effect of incremental levels of sunflower-seed oil in the diet on ruminal lipid metabolism in lactating cows. British Journal of Nutrition, 99, 971-983. https://doi.org/10.1017/S0007114507853323

Shingfield, K. J., Reynolds, G. K., Hervás, G., Griinari, J. M., Grandison, A. S., \& Beever, D. E. (2006). Examination of the persistency of milk fatty acid composition responses to fish oil and sunflower oil 
in the diet of dairy cows. Journal of Dairy Science, 89(2), 714-732. https://doi.org/10.3168/jds.S00220302(06)72134-8

Tjørve, K. M. C., \& Tjørve, E. (2017). The use of Gompertz models in growth analyses, and new Gompertzmodel approach: An addition to the Unified-Richards family. PLoS ONE, 12(6), 1-17. https://doi. org/10.1371/journal.pone.0178691

Toral, P. G., Belenguer, A., Frutos, P., \& Hervás, G. (2009). Effect of the supplementation of a high-concentrate diet with sunflower and fish oils on ruminal fermentation in sheep. 81, 119-125. https://doi.org/10.1016/j. smallrumres.2008.12.009

Ueda, K., Ferlay, A., Chabrot, J., Loor, J. J., Chilliard, Y., \& Doreau, M. (2003). Effect of Linseed Oil Supplementation on Ruminal Digestion in Dairy Cows Fed Diets with Different Forage: Concentrate Ratios. Journal of Dairy Science, 86(12), 3999-4007. https://doi.org/10.3168/jds.S0022-0302(03)74011-9

Vargas, J. E., Andrés, S., López-Ferreras, L., Snelling, T. J., Yáñez-Ruíz, D. R., García-Estrada, C., \& López, S. (2020). Dietary supplemental plant oils reduce methanogenesis from anaerobic microbial fermentation in the rumen. Scientific Reports, 10(1), 1-9. https://doi.org/10.1038/s41598-020-58401-z

Wachira, A. M., Sinclair, L. A., G., W. R., Hallett, K., Enser, M., \& Wood,J. D. (2000). Rumen biohydrogenation of $\mathrm{n}-3$ polyunsaturated fatty acids and their effects on microbial efficiency and nutrient digestibility in sheep. Journal of Agricultural Science, 135, 419-428.

Wąsowska, I., Maia, M. R. G., Niedźwiedzka, K. M., Czauderna, M., Ramalho Ribeiro, J. M. G., Devillard, E., ... Wallace, R. J. (2006). Influence of fish oil on ruminal biohydrogenation of C18 unsaturated fatty acids. British Journal of Nutrition, 95(6), 1199-1211. https://doi.org/10.1079/bjn20061783

Whigham, L. D., Watras, A. C., \& Schoeller, D. A. (2018). Efficacy of conjugated linoleic acid for reducing fat mass : a meta-analysis in humans 1, 2. American Society for Nutrition, (February), 1203-1211.

Yang, S. L., Bu, D. P., Wang, J. Q., Hu, Z. Y., Li, D., Wei, H. Y., ... Loor, J. J. (2009). Soybean oil and linseed oil supplementation affect profiles of ruminal microorganisms in dairy cows. Animal, 1562-1569. https://doi.org/10.1017/S1751731109990462

Zhang, C. M., Guo, Y. Q., Yuan, Z. P., Wu, Y. M., Wang, J. K., Liu, J. X., \& Zhu, W. Y. (2008). Effect of octadeca carbon fatty acids on microbial fermentation, methanogenesis and microbial flora in vitro. Animal Feed Science and Technology, 146(3-4), 259-269. https://doi.org/10.1016/j.anifeedsci.2008.01.005 